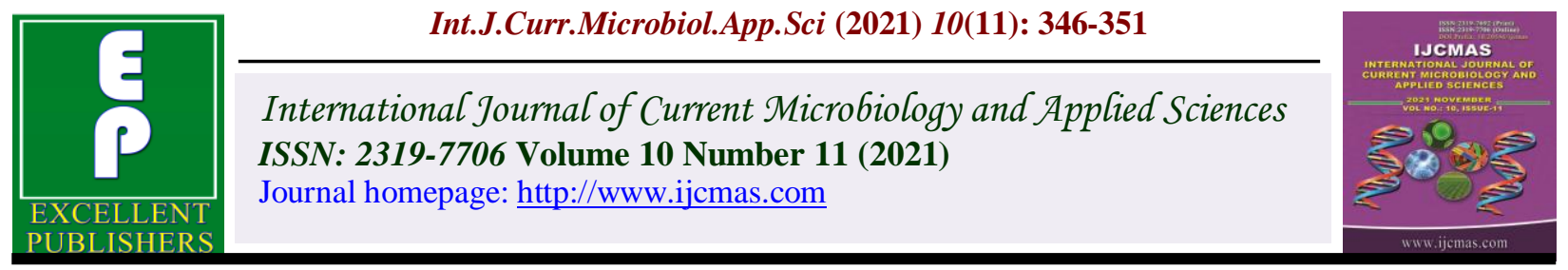

Original Research Article

https://doi.org/10.20546/ijcmas.2021.1011.039

\title{
Effect of Iron and Zinc on Growth, Yield and Quality of Cowpea (Vigna unguiculata L.) under South Gujarat Condition
}

\author{
V. A. Dobariya and A. P. Patel*
}

Department of Agronomy, N. M. College of Agriculture, Navsari Agricultural University, Navsari-396450, Gujarat, India

*Corresponding author

\begin{tabular}{l}
\hline K e y w o r d s \\
$\begin{array}{l}\text { Cowpea, Iron, Zinc, } \\
\text { immature pods, } \\
\text { Vigna unguiculata } \\
\text { L }\end{array}$ \\
\hline Article Info \\
$\begin{array}{l}\text { Received: } \\
\text { 15 October } 2021 \\
\text { Accepted: } \\
\text { 02 November } 2021 \\
\text { Available Online: } \\
10 \text { November } 2021\end{array}$ \\
\hline
\end{tabular}

\section{Keywords}

Cowpea, Iron, Zinc immature pods, Vigna unguiculata

\section{Received:}

15 October 2021

Acepted:

Available Online:

10 November 2021

\section{A B S T R A C T}

A field experiment was carried out at College Farm, Navsari Agricultural University, Navsari on clayey soils during summer season of the year 2019 to study the Effect of iron and zinc on growth, yield and quality of cowpea (Vigna unguiculata L.) under south Gujarat condition. The results of experiment indicated that growth and yield attributes viz., plant height at 60 DAS and at harvest, number of branches per plant, number of nodules per plant, number of pods per plant, pod length, seed and haulm yield (955 and $2008 \mathrm{~kg} / \mathrm{ha}$, respectively) and test weight increased significantly with soil application of $\mathrm{FeSO}_{4} @ 25.0 \mathrm{~kg} / \mathrm{ha}$ which was significantly higher over control but remained at par with soil application of $12.5 \mathrm{~kg} \mathrm{FeSO}_{4} / \mathrm{ha}$. Similarly zinc is also an essential plant nutrient for plant growth and yield. Zinc application had also positive effect on growth and yield attributes viz., plant height at 60 DAS and at harvest, number of branches per plant, number of nodules per plant, number of pods per plant, pod length, seed and haulm yield (972 and $2030 \mathrm{~kg} / \mathrm{ha}$, respectively) and test weight increased significantly with soil application of $\mathrm{ZnSO}_{4} @ 25.0 \mathrm{~kg} / \mathrm{ha}$ which was significantly higher over control but remained at par with soil application of $12.5 \mathrm{~kg}$ $\mathrm{ZnSO}_{4} /$ ha. Significant improvement in protein content in seed with soil application of both $\mathrm{FeSO}_{4}$ and $\mathrm{ZnSO}_{4} @ 25.0 \mathrm{~kg} / \mathrm{ha}$.

\section{Introduction}

The Cowpea (Vigna unguiculata L.) belongs to the family Leguminoceae and sub family fabaceae, considered as long green pods as vegetables, seeds and pulses, as foliage, as green manure, as well as green fodder. The cultivars grown for their immature pods are variously known as 'Asparagus bean', 'Snake bean' and 'Yard long bean'. Cowpea seeds are nutritious component in the human diet as well as for livestock feed. The protein in the cowpea seed is rich in amino acids, viz., lysine and tryptophan as compared to cereal grains. Cowpea seeds contain 54.5 per cent carbohydrates, 24.1 per cent protein and 0.1 per cent fat. Zinc is one of the essential micronutrients and plays important role in 
various enzymatic and physiological activities of the plant. It is also essential for photosynthesis and N-metabolism and important for the stability of cytoplasmic ribosome's, cell division, dehydrogenase, proteinase, peptidase enzymes and in the synthesis of tryptophan, a component of some proteins and a compound needed for production of growth hormones (auxin) such as indole acetic acid. Reduced growth hormone production in zinc deficient plants causes the shorting of internodes and smaller leaves. Iron plays an important role in synthesis and maintenance of chlorophyll in plant. It helps in the formation of chlorophyll and it is an important constituent of the enzyme nitrogenase, which is essential for nitrogen fixation (Yadav et al., 2002). It has an essential role in nucleic acid metabolism. Application of iron fertilizer for crop production also reduces the malnourishment in human and animals. Iron deficiency is one of the major limiting factors affecting crop yields. Therefore, approaches need to be developed to increase iron uptake by roots, transfer to edible plant portions and absorption by human from plant food sources. Application of iron fertilizers in cowpea crop production may be a better sustainable option to overcome these problems in the future.

\section{Materials and Methods}

A field experiment was conducted during summer season of the year 2019 at College Farm, Navsari Agricultural University, Navsari. The soil of experimental field was clayey in texture and slightly alkaline in reaction with $\mathrm{pH} 7.68$ and EC $0.38 \mathrm{dS} / \mathrm{m}$, medium in organic carbon $(0.52 \%)$, low in available $\mathrm{N}(238.6 \mathrm{~kg} / \mathrm{ha})$, medium in available $\mathrm{P}_{2} \mathrm{O}_{5}(50.8 \mathrm{~kg} / \mathrm{ha})$ and high in available $\mathrm{K}_{2} \mathrm{O}(356.2 \mathrm{~kg} / \mathrm{ha})$. The soil was medium in available iron $(5.16 \mathrm{mg} / \mathrm{kg}$ ) and zinc $(0.68 \mathrm{mg} / \mathrm{kg})$. The experiment was laid out in randomized block design with factorial concept (FRBD) with four replications. Total nine treatment combinations consisting of three levels of iron (control $(0 \mathrm{~kg} / \mathrm{ha})$, soil application of $\mathrm{FeSO}_{4} @ 12.5 \mathrm{~kg} / \mathrm{ha}$ and soil application of $\mathrm{FeSO}_{4} @ 25.0 \mathrm{~kg} / \mathrm{ha}$ ) and three levels of zinc (control $(0 \mathrm{~kg} / \mathrm{ha})$, soil application of $\mathrm{ZnSO}_{4} @ 12.5 \mathrm{~kg} / \mathrm{ha}$ and soil application of $\mathrm{ZnSO}_{4} @ 25.0 \mathrm{~kg} / \mathrm{ha}$ ). Cowpea variety "GC-4" was sown on $25^{\text {th }}$ February 2019 and recommended dose of fertilizer was $20-40-00 \mathrm{~N}-\mathrm{P}-\mathrm{K} \mathrm{kg} / \mathrm{ha}$ and using seed rate 25 $\mathrm{kg} / \mathrm{ha}$ with raw spacing $45 \mathrm{~cm}$ and plant spacing $10 \mathrm{~cm}$ and crop was harvested at $23^{\text {rd }}$ May 2019. The observation on Growth attributes, Yield and yield attributes and Quality parameters was recorded. Statistical analysis of the individual data of various characters studied in the experiment was carried out using standard statistical procedures as described by Panse and Sukhatme (1985).

\section{Results and Discussion}

\section{Effect of iron}

It is apparent from data presented in (Table 1 and 2.), indicated that maximum plant height at 60 DAS and at harvest, number of branches per plant, number of nodules per plant, number of pods per plant, pod length, seed and haulm yield and test weight was recorded with soil application of $25.0 \mathrm{~kg} \mathrm{FeSO} / 4$ ha which was significantly higher over control but remained at par with soil application of 12.5 $\mathrm{kg} \mathrm{FeSO}_{4} / \mathrm{ha}$. soil application of $25.0 \mathrm{~kg}$ $\mathrm{FeSO}_{4} /$ ha registering 8.23 and 12.28 per cent higher in plant height at harvest, 12.20 and 19.31 per cent in number of branches per plant, 4.47 and 9.86 per cent in number of nodules per plant, 14.33 and 21.63 per cent number of pods per plant, 13.16 and 15.32 per cent in pod length, 8.24 and 13.71 per cent in seed yield, 6.79 and 12.54 per cent in haulm yield and 12.71 and 14.79 per cent in test weight over control, respectively. 
Table.1 Effect of iron and zinc levels on growth attributes of cowpea

\begin{tabular}{|c|c|c|c|c|}
\hline \multirow[t]{2}{*}{ Treatments } & \multicolumn{2}{|c|}{ Plant height (cm) } & \multirow{2}{*}{$\begin{array}{c}\text { Number of branches } \\
\text { per plant }\end{array}$} & \multirow{2}{*}{$\begin{array}{c}\text { Number of nodules } \\
\text { per plant }\end{array}$} \\
\hline & 60 DAS & At harvest & & \\
\hline \multicolumn{5}{|c|}{ (A) Levels of iron } \\
\hline$A_{1}:$ Control (0 kg/ha) & 32.36 & 42.13 & 5.18 & 45.51 \\
\hline $\begin{array}{c}\mathrm{A}_{2} \text { : Soil application of } \mathrm{FeSO}_{4} @ 12.5 \\
\mathrm{~kg} / \mathrm{ha}\end{array}$ & 35.13 & 45.91 & 5.90 & 47.64 \\
\hline $\begin{array}{c}A_{3}: \text { Soil application of } \mathrm{FeSO}_{4} @ 25.0 \\
\mathrm{~kg} / \mathrm{ha}\end{array}$ & 36.63 & 48.03 & 6.42 & 50.49 \\
\hline S.Em. \pm & 0.79 & 1.07 & 0.18 & 1.25 \\
\hline C.D. at $5 \%$ & 2.31 & 3.14 & 0.53 & 3.65 \\
\hline \multicolumn{5}{|c|}{ (B) Levels of zinc } \\
\hline B $_{1}:$ Control $(0 \mathrm{~kg} / \mathrm{ha})$ & 32.05 & 41.81 & 5.00 & 45.33 \\
\hline $\begin{array}{c}\mathrm{B}_{2} \text { : Soil application of } \mathrm{ZnSO}_{4} @ 12.5 \\
\mathrm{~kg} / \mathrm{ha}\end{array}$ & 35.28 & 45.95 & 6.04 & 47.68 \\
\hline $\begin{array}{c}\mathrm{B}_{3} \text { : Soil application of } \mathrm{ZnSO}_{4} @ 25.0 \\
\mathrm{~kg} / \mathrm{ha}\end{array}$ & 36.79 & 48.32 & 6.46 & 50.64 \\
\hline S.Em. \pm & 0.79 & 1.07 & 0.18 & 1.25 \\
\hline C.D. at $5 \%$ & 2.31 & 3.14 & 0.53 & 3.65 \\
\hline C.V. \% & 7.88 & 8.21 & 10.75 & 9.06 \\
\hline Interaction (Fe x Zn) & NS & NS & NS & NS \\
\hline
\end{tabular}


Table.2 Effect of iron and zinc levels on yield and yield attributes and protein content of cowpea

\begin{tabular}{|c|c|c|c|c|c|c|c|}
\hline Treatments & $\begin{array}{c}\text { Number of } \\
\text { pods per } \\
\text { plant }\end{array}$ & $\begin{array}{c}\text { Pods } \\
\text { length } \\
(\mathrm{cm})\end{array}$ & $\begin{array}{c}\text { Seed } \\
\text { yield } \\
\text { (kg/ha) }\end{array}$ & $\begin{array}{l}\text { Haulm } \\
\text { yield } \\
\text { (kg/ha) }\end{array}$ & $\begin{array}{c}\text { Test } \\
\text { weight } \\
\text { (g) }\end{array}$ & $\begin{array}{c}\text { Harvest } \\
\text { index }(\%)\end{array}$ & $\begin{array}{c}\text { Protein } \\
\text { content } \\
(\%)\end{array}$ \\
\hline \multicolumn{8}{|c|}{ (A) Levels of iron } \\
\hline$A_{1}:$ Control $(0 \mathrm{~kg} / \mathrm{ha})$ & 11.59 & 9.89 & 824 & 1756 & 11.40 & 31.88 & 20.27 \\
\hline $\mathrm{A}_{2}$ : Soil application of $\mathrm{FeSO}_{4} @ 12.5 \mathrm{~kg} / \mathrm{ha}$ & 13.53 & 11.39 & 898 & 1884 & 13.06 & 32.30 & 20.97 \\
\hline $\mathrm{A}_{3}$ : Soil application of $\mathrm{FeSO}_{4} @ 25.0 \mathrm{~kg} / \mathrm{ha}$ & 14.79 & 11.68 & 955 & 2008 & 13.38 & 32.24 & 21.60 \\
\hline S.Em. \pm & 0.45 & 0.31 & 25.69 & 46.86 & 0.15 & 0.61 & 0.34 \\
\hline C.D. at $5 \%$ & 1.32 & 0.92 & 75.0 & 136.79 & 0.45 & NS & 1.00 \\
\hline \multicolumn{8}{|c|}{ (B) Levels of zinc } \\
\hline$B_{1}:$ Control (0 kg/ha) & 11.40 & 9.64 & 804 & 1722 & 11.27 & 31.80 & 19.70 \\
\hline $\mathrm{B}_{2}$ : Soil application of $\mathrm{ZnSO}_{4} @ 12.5 \mathrm{~kg} / \mathrm{ha}$ & 13.68 & 11.50 & 901 & 1896 & 13.12 & 32.23 & 21.23 \\
\hline $\mathrm{B}_{3}$ : Soil application of $\mathrm{ZnSO}_{4} @ 25.0 \mathrm{~kg} / \mathrm{ha}$ & 14.84 & 11.82 & 972 & 2030 & 13.45 & 32.39 & 21.90 \\
\hline S.Em. \pm & 0.45 & 0.31 & 25.69 & 46.86 & 0.15 & 0.61 & 0.34 \\
\hline C.D. at $5 \%$ & 1.32 & 0.92 & 75.0 & 136.79 & 0.45 & NS & 1.00 \\
\hline C.V. \% & 11.79 & 9.96 & 9.98 & 8.62 & 4.23 & 6.67 & 5.68 \\
\hline Interaction (Fe x Zn) & NS & NS & NS & NS & NS & NS & NS \\
\hline
\end{tabular}


This might be due to its role in starch formation and protein synthesis as well as maintenance and synthesis of chlorophyll in plants. The increase in the availability of iron to plant might have stimulated the metabolic and enzymatic activities thereby increasing the growth of the crop. Similar findings were also reported by Kuldeep et al., (2018), The application of iron significantly increased the yield characteristics in cowpea. The yield of cowpea is the cumulative effect of growth attributing characters and yield characters such as pods per plant. These findings are in confirmation by Pooja and Sarawad (2019) and Doodhwal et al., (2020).

The highest protein content in seed was recorded with soil application of $25.0 \mathrm{~kg}$ $\mathrm{FeSO}_{4} /$ ha which was significantly higher over control but remained at par with soil application of $12.5 \mathrm{~kg} \quad \mathrm{FeSO}_{4} / \mathrm{ha}$ soil application of $25.0 \mathrm{~kg} \mathrm{FeSO} / 4$ ha increased the protein content in seed by 3.33 and 6.15 per cent over control, respectively. This might be due to significant increase in protein content in seed with the application of iron may also be attributed to the fact that application of iron to the soil might have increased the activity of Rhizobium bacteria resulting into increased atmospheric nitrogen fixation and obviously better utilization of soil nitrogen by the crop these findings were confirmed by Pooja and Sarawad (2019).

\section{Effect of zinc}

The highest plant height at 60 DAS and at harvest, number of branches per plant, number of nodules per plant, number of pods per plant, pod length, seed and haulm yield and test weight was recorded with soil application of $25.0 \mathrm{~kg} \mathrm{ZnSO}_{4} /$ ha which was significantly higher over control but remained at par with soil application of $12.5 \mathrm{~kg} \mathrm{ZnSO}_{4} / \mathrm{ha}$. The corresponding increases with soil application of $25.0 \mathrm{~kg} \mathrm{ZnSO} / \mathrm{ha}$ was 9.01 and 13.47 per cent in plant height at harvest, 17.21 and 22.60 per cent in number of branches per plant, 4.92 and 10.48 per cent in number of nodules per plant, 16.66 and 23.18 per cent number of pods per plant, 16.17 and 18.44 per cent in pod length, 10.76 and 17.28 per cent in seed yield, 9.17 and 15.17 per cent in haulm yield and 14.10 and 16.20 per cent in test weight over control, respectively. Zinc plays a pivotal role in cellular growth, differentiation and metabolism which results in vigorous growth of plants and extensive root system leading to increased growth and yield attributes. Similar results were also reported by Kuldeep et al., (2018).

It is indicated that the maximum protein content in seed was recorded with soil application of $25.0 \mathrm{~kg} \mathrm{ZnSO} / \mathrm{ha}$ which was significantly higher over control but remained at par with soil application of $12.5 \mathrm{~kg}$ $\mathrm{ZnSO}_{4} / \mathrm{ha}$. soil application of $25.0 \mathrm{~kg}$ $\mathrm{ZnSO}_{4}$ /ha was recorded 7.20 and 10.04 per cent higher protein content in seed over control, respectively. It might due to increased availability of zinc which improved the content and uptake of nitrogen in plants, resulting in higher protein content in seed. These results are in line with Habib et al., (2018).

On the basis of one year experimental data, it may be concluded that higher growth, yield and nutritional quality of cowpea can be obtained with the combined soil application of $\mathrm{FeSO}_{4}$ and $\mathrm{ZnSO}_{4} @ 12.5 \mathrm{~kg} / \mathrm{ha}$, each under south Gujarat agro climatic condition.

\section{References}

Anonymous (2007). Directorate of pulse Development (Bhopal). Annual Progress Report, Integrated Scheme of Oilseeds, Pulse, Oil palm and Maize (ISOPOM) - Pulses.

Doodhwal, K., Yadav, B. L., Yadav, M. and 
Choudhary, M. (2020). Impact of sodium and iron levels on yield, nutrient content and uptake by cowpea (Vigna unguiculata L.). Legume Research-An International Journal, 43(4): 558-562.

Habib, A. A., Roy, T. S., Amin, M. R., Haque, M. Z., Rokonuzzaman, M. and Sarker, P. (2018). Response of zinc on growth, yield and quality of blackgram (Vigna mungo L.). International Journal of Agronomy and Agricultural Research, 13(4): 73-79.

Kuldeep, Kumawat, P. D., Bhadu, V., Sumeriya, H. K. and Kumar, V. (2018). Effect of iron and zinc nutrition on growth attributes and yield of chickpea (Cicer arietinum L.) International Journal of current Microbiology and Applied Sciences, 7(8): 2837-2841.
Panse, V. G. and Sukhatme, P. V. (1967). Statistical methods for agricultural workers. ICAR, New Delhi. Pp. 187197.

Pooja, C. and Sarawad, I. M. (2019). Influence of iron and zinc on yield, quality of chickpea and status of iron and zinc in post harvest soil. Agric. Sci. Digest., 39(1): 31-35.

Takkar, P. N. and Randhawa, N. S. (1978). Micronutrients in Indian AgricultureA Review. Fertilizer News, 23: 8-26.

Tisdale, S. L., Nelson, W. L., Beaton, J. D. and Halvin, J. L. (1993). Soil Fertility and Fertilizer. 5th Ed. Prentice Hall of India Private Ltd., New Delhi.

Yadav, P. S., Kamriya, P. R. and Rathore, S. (2002). Effect of iron fertilization on yield, protein content and nutrient uptake in mungbean. Journal of Indian Society of Soil Science, 50: 225-226.

\section{How to cite this article:}

Dobariya, V. A. and Patel, A. P. 2021. Effect of Iron and Zinc on Growth, Yield and Quality of Cowpea (Vigna unguiculata L.) under South Gujarat Condition. Int.J.Curr.Microbiol.App.Sci. 10(11): 346-351. doi: https://doi.org/10.20546/ijcmas.2021.1011.039 